\title{
Enhancing genetic fitness while maintaining genetic variability in Araucaria angustifolia
}

\author{
Melhorar a aptidão genética, mantendo a variabilidade genética de \\ Araucaria angustifolia
}

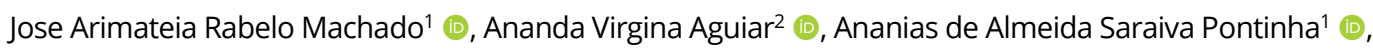
Bruno Marchetti Souza ${ }^{3}$ (D), Alexandre Magno Sebbenn ${ }^{1}$ (1), John Edward Hallsworth ${ }^{4}$ (1), Valderês Aparecida Sousa² (D), Miguel Luiz Menezes Freitas ${ }^{1}$ (i)

${ }^{1}$ Instituto Florestal de São Paulo - IF, São Paulo, SP, Brasil

${ }^{2}$ Empresa Brasileira de Pesquisa Agropecuária - Embrapa Florestas, Colombo, PR, Brasil

3Faculdade de Engenharia de Ilha Solteira, Universidade Estadual Paulista "Júlio de Mesquita Filho"- UNESP, Ilha Solteira SP, Brasil

${ }^{4}$ Institute for Global Food Security, School of Biological Sciences, Queen's University Belfast, Chlorine Gardens, Belfast, United Kingdom

How to cite: Machado, J. A. R., Aguiar, A. V., Pontinha, A. A. S., Souza, B. M., Sebbenn, A. M., Hallsworth, J. E., Sousa, V. A., \& Freitas, M. L. M. (2021). Enhancing genetic fitness while maintaining genetic variability of Araucaria angustifolia. Scientia Forestalis, 49(130), e3572. https://doi.org/10.18671/scifor.v49n130.20

\begin{abstract}
Araucaria angustifolia provides timber, edible seeds and pharmaceuticals and has a unique ecology (once shared with that of the dinosaurs), yet is now threatened with extinction. Here, we assess and reconcile the counteracting goals of enhancing genetic fitness and maintaining genetic variability during ex-situ conservation of $A$. angustifolia in a provenance-and-progeny test to improve growth vigor. After 33 years, survival, height, diameter at breast height, and volume of trees were determined. Sixteen selection scenarios were tested using two strategies: selection among and within progenies, and selection only within progenies, each one for eight values of selection intensity of total survival in the trial $(7.6,11.5$, $15.3,19.1,22.9,26.8,30.6$, and 34.4\%). The variance components and genetic parameter estimates were determined using REML/BLUP. There was significant genetic variation among provenances and progenies for all traits. For all growth-phenotype traits, the heritability at mean (0.419-0.542) and within progeny level (0.186-0.207) indicate the potential for tree improvement by selection among and within progenies. The selection strategy enhanced growth phenotype whilst maintaining an effective population size of $19.1 \%$ selected individuals within progenies (three females and two males). This preserved sufficient genetic variability among and within provenances, and resulted in genetic gain, providing higher-value seed production.
\end{abstract}

Keywords: Araucaria angustifolia; Coniferous; Genetic conservation; Gymnosperm; Quantitative genetics; Tree breeding.

\section{Resumo}

Araucaria angustifolia fornece madeira, sementes comestíveis e fármacos e possui uma ecologia única (antes compartilhada com a dos dinossauros), mas agora está ameaçada de extinção. Aqui, avaliou-se e reconciliou-se objetivos contrários de aumentar a aptidão genética e manter a variabilidade genética durante a conservação ex-situ de $A$. angustifolia em um teste de procedencias e progênie para melhorar o vigor de crescimento. Após 33 anos do plantio, a altura, o diâmetro à altura do peito, volume e a sobrevivência das árvores foram medidos. Os componentes da variância e as estimativas dos parâmetros genéticos foram determinados utilizando o método REML/BLUP. Dezesseis cenários de seleção foram testados usando duas estratégias: seleção entre e dentro das progênies, e seleção apenas dentro das progênies, cada um para oito intensidades de seleção de árvores de sobrevivência total no ensaio (7,6,

Financial support: None.

Conflict of interest: Nothing to declare

Correspondig author: miguellmfreitas@yahoo.com.br

Received: 9 July 2020.

Accepted: 23 October 2020.

Editor: Paulo Henrique Müller Silva.

(c) This is an Open Access article distributed under the terms of the Creative Commons Attribution License, which permits unrestricted use,

c. distribution, and reproduction in any medium, provided the original work is properly cited. 
$11,5,15,3,19,1,22,9,26,8,30,6$ e 34,4\%). Variação genética significativa entre procedências e progênies foi detectada para todos os caracteres. Para todos os caracteres de crescimento, a herdabilidade no nível médio $(0,419-0,542)$ e dentro das progênies $(0,186-0,207)$ mostrou a possibilidade de melhoramento da população pela seleção entre e dentro da progênie. A estratégia de seleção mais eficaz para melhorar o fenótipo de crescimento, mantendo um tamanho efetivo da população próximo ao original foi a seleção de 19,1\% dos indivíduos dentro das progênies (três fêmeas e dois machos). Isso preservou variabilidade genética suficiente entre e dentro das procedências e resultou em ganho genético, possibilitando a produção de sementes de maior valor.

Palavras-chave: Araucaria angustifolia; Conífera; Conservação genética; Gimnosperma; Genética quantitativa; Melhoramento florestal.

\section{INTRODUCTION}

Forest fragmentation and deforestation have caused biodiversity loss and increased the risk of local extinctions (Haddad et al., 2015). Araucaria forest, also known as Tropical Humid Mixed Forest, is dominated by the majestic architecture of a gymnosperm, Araucaria angustifolia (Bert.) O. Kuntze. The ancestors of these ancient trees once shared their ecology with that of the dinosaurs (Hummel et al., 2008). Whereas Araucaria forests used to occupy 20 million hectares, mostly in mountain- and plateau regions of Southern Brazil but also in pockets within highlands of Southeast Brazil, Argentina and Paraguay (Reitz \& Klein, 1966; Reis et al., 2018). Now, less than 7\% of the original Araucaria forest remains (Reis et al., 2018). The extensive and intensive deforestation of the Atlantic Forest has fragmented populations of $A$. angustifolia and this, combined with historical logging, has driven the species closer to extinction (Lacerda, 2016); it now features in the IUCN Red List as critically endangered (The World Conservation Union). Araucaria forest is a habitat that characteristically has endemic species and a unique and complex ecology at a range of trophic levels (Zandavalli \& Dillenburg, 2015; Pereira et al., 2020). In addition, A. angustifolia has unique metabolites and physiology, and is valued for timber, edible seeds, and medicinal properties (Perotti et al., 2015; Peralta et al., 2016; Fonseca et al., 2020). There is, therefore, an urgent need to conserve genetic resources of this tree.

Regarding long-term conservation, the preservation of original habitat containing in-situ populations is best; to avoid any discontinuity of ecological and evolutionary processes (Flower et al., 2018). However, this strategy would demand the creation and expansion of legally protected areas, which implies high costs. Furthermore, considering that the remnants of the ancient Araucaria forest are now very small in some regions, strategies for in-situ conservation may no longer be sufficient to effectively protect $A$. angustifolia genetic resources (Bittencourt \& Sebbenn, 2007; Medina-Macedo et al., 2016; Lacerda, 2016; Reis et al., 2018). Ex-situ plantations, established in provenance-and-progeny trials can be used as a complementary strategy to guarantee the genetic conservation of $A$. angustifolia (Zechini et al., 2018). Provenance-and-progeny trials also provide the biological material for breeding and seed-production programs (Aguiar et al., 2019).

Despite being one of the most-studied tree species in Brazil for in-situ and ex-situ genetic conservation, using quantitative traits (Pires et al., 1983; Sebbenn et al., 2003a, 2004; Silva et al., 2018), isozymes (Auler et al., 2002; Mantovani et al., 2006; Ferreira et al., 2012; Zechini et al., 2018), and DNA markers (Bittencourt \& Sebbenn, 2009; Duarte et al., 2012; Danner et al., 2013; Sant'Anna et al., 2013; Medina-Macedo et al., 2016; Stefenon et al., 2019; Silva et al., 2020), A. angustifolia lacks a solid breeding program (Sousa et al., 2020).

The demand for seeds of native tree species has increased in the last decade, mainly for use in large-scale Atlantic Forest habitat-restoration projects and reforestation for commercial timber production (Schmidt et al., 2019; Urzedo et al., 2019). Provenanceand-progeny test plots can be used as an efficient and cost-effective source of highquality seeds for this growing market (Aguiar et al., 2019). Considering the economic aspect, conservation combined with use can form the basis of more-viable public policies regarding the conservation of the species' genetic resources. Participatory plant breeding, as proposed by the Empresa Brasileira de Pesquisa Agropecuária (EMBRAPA) 
and its partners (Instituto Florestal de São Paulo, universities, farmers, and forest companies), can also contribute to the conservation of this species. Participatory plant breeding is applied mainly to forest species that have economic, social, and environmental value for a given community or group of stakeholders (Reis et al., 2018). Thus, the stakeholder (typically a vendor or manufacturer of products) participates in some or all stages of the development process of new cultivars, which better meet the needs of the producers (Reis et al., 2018). This conservation-through-use strategy can reduce exploitation pressure on forest remnants, thus alleviating genetic erosion (Reis et al., 2018). Ex-situ provenance-and-progeny-trial plantations have also the advantage of gathering genotypes from several provenances in a single area, enabling the continuous evaluation of tree performance and the estimation of genetic parameters, as heritability and genetic gains (Aguiar et al., 2019). The estimation of genetic parameters is a necessary step for the conversion of provenance-and-progeny trials into seedling seed-orchards (Aguiar et al., 2019). The conversion is based on the identification of desirable trees by selective thinning of inferior trees (Aguiar et al., 2019; Goldringer et al., 2020) where the main challenge is to reconciling potentially conflicting objectives in the same trial, i.e., to guarantee the maintenance of genetic diversity for ex-situ conservation whilst at the same time achieving genetic gain for environmental reforestation.

The overarching goals of this study were to convert an A. angustifolia provenanceand-progeny test into a seedling seed-orchard, produce improved seeds for commercial reforestations, test different selection strategies, and produce a knowledge-based strategy for the genetic conservation and improvement of $A$. angustifolia. The specific objectives were to: (i) estimate the genetic parameters in a provenance-and-progeny test; (ii) identify superior trees from their growth phenotype; (iii) estimate genetic gains by comparing different combinations of selection intensities and methods; and (iv) propose an appropriate selective thinning regime to convert the provenance-andprogeny test into a seedling seed-orchard.

\section{MATERIAL AND METHODS}

\section{Sampling and experimental design}

The study was carried out in as part of a provenance-and-progeny test established in 1982 at the Itapeva Experimental Station of the São Paulo Forest Institute, Brazil (241 ${ }^{\prime}$ $\mathrm{S}, 48^{\circ} 54^{\prime} \mathrm{W}$, and $930 \mathrm{~m}$ above sea level). Seeds were collected in 1981 from five natural populations of $A$. angustifolia (Table 1). Three of these populations were located within São Paulo state, at Campos do Jordão (CJ), Cunha (CU) and Itararé (IT), and the two other populations were located within Santa Catarina state, at São Joaquim (SJ) and Bom Jardim da Serra (BJS). Open-pollinated seeds were collected from random trees (from 14 to 26 trees per provenance) whilst respecting a minimum distance of $100 \mathrm{~m}$ between trees to avoid the collection of seeds from genetically related parents. The seedlings were germinated in polyethylene bags and planted in April of 1982 (Sebbenn et al., 2003b). The climate at the planting site is for the most part dry, with annual rainfall concentrated in summer. The average annual temperature is $18.6{ }^{\circ} \mathrm{C}$, average annual rainfall is $1,300 \mathrm{~mm}$, and the predominant soil types are dystrophic red latosols (Sebbenn et al., 2003b). We employed a compact family randomized block design with three blocks, five plots (provenances), 14 to 26 subplots (progenies/provenances), 10 plants per subplot, and a spacing of $3 \times 2 \mathrm{~m}$. To minimize any potential edge effects, two border rows were planted, using the same species (Sebbenn et al., 2003b). It was not possible to determine the percentage of female and male trees in the trial. 
Table 1. Geographic, climatic and sampling progeny $\left(n_{p}\right)$ information of the sampled Araucaria angustifolia provenances.

\begin{tabular}{cccccc}
\hline Provenance & $n_{p}$ & $\begin{array}{c}\text { Geographical } \\
\text { coordinates }\end{array}$ & $\begin{array}{c}\text { Elevation } \\
\mathbf{( m )}\end{array}$ & $\begin{array}{c}\text { Mean min.-max. } \\
\text { temperatures } \\
\left.\mathbf{(}^{\circ} \mathbf{C}\right)\end{array}$ & $\begin{array}{c}\text { Mean } \\
\text { annual } \\
\text { rainfall } \\
(\mathbf{m m})\end{array}$ \\
\hline Campos do Jordão, SP (C) & 26 & $22^{\circ} 44^{\prime} \mathrm{S} 45^{\circ} 30^{\prime} \mathrm{W}$ & 1,630 & $15.0-22.0$ & 1,891 \\
Cunha, SP (CU) & 14 & $23^{\circ} 14^{\prime} \mathrm{S} 43^{\circ}$ 03'W & 970 & $14.1-20.6$ & 2,000 \\
Itararé, SP (IT) & 21 & $24^{\circ} 30^{\prime} \mathrm{S} 49^{\circ} 10^{\prime} \mathrm{W}$ & 930 & $18.0-22.0$ & 1,500 \\
São Joaquim, SC (SJ) & 24 & $28^{\circ} 19^{\prime} \mathrm{S} 49^{\circ} 52^{\prime} \mathrm{W}$ & 1,380 & $9.2-17.3$ & 1,600 \\
Bom Jardim da Serra, SC (BJS) & 25 & $28^{\circ} 18^{\prime} \mathrm{S} 49^{\circ} 32^{\prime} \mathrm{W}$ & 800 & $9.1-17.3$ & 1,600 \\
\hline
\end{tabular}

SP is state of São Paulo; SC is state of Santa Catarina; min. and max. are minimum and maximum.

The trial was evaluated (33 years after planting) for the following traits: mean surviving trees per plot, total height $(\mathrm{H})$ measured using a hypsometer, and diameter at breast height $(\mathrm{dbh}, \mathrm{cm})$ measured with tape graduated to $0.1 \mathrm{~cm}$. True individual volume without bark (Vol, $\mathrm{m}^{3}$.tree ${ }^{-1}$ ) was calculated according to Shimizu (1999) by, $\mathrm{Vol}=0.01765474+0.3966295(\mathrm{dbh} / 100)^{2} \mathrm{H}$. The mean annual increment ( MAI ) was calculated for $\mathrm{H}, \mathrm{dbh}$, and $\mathrm{Vol} b y: M A I=x / a$, where $x$ is the observed value of a trait and $a \mathrm{y}$ is the age of the trial.

\section{Estimation of variance components and genetic parameters}

Due to the unbalanced numbers of progeny per provenances and survival within the plot, the univariate additive mixed linear model implemented in the SELEGENREML/BLUP software (Resende, 2016) was used to estimate the variance components and the genetic parameters. Two linear mixed models were employed using the REML/BLUP procedure to obtain the genetic values at individual level. Deviance analyses were performed to test the significance of the model effects through the likelihood-ratio test (LRT). The first model included the effect of provenances, represented by: $y=X_{b}+Z_{a}+W_{p}+T_{s}+e$ and, the second model did not include the provenance effect: $y=X_{b}+Z_{a}+W_{p}+e$, where $y$ is the data vector, $b$ represents the block effects (fixed), $a$ represents the individual additive genetic effects (random), $p$ represents the plot effects (random), $s$ is the provenance effects (random), and $e$ is the residual (random). $X, Z, W$ , and $T$ represent the incidence matrices for the referred effects (Resende, 2002). The following variance components and genetic parameters were estimated: genetic variance among progenies within provenances $\left(\sigma_{p(p)}^{2}\right)$, additive genetic variance ( $\left.\sigma_{a}^{2}=4 \sigma_{p(p)}^{2}\right)$, environmental variance among plots $\left(\sigma_{c}^{2}\right)$, genetic variance among

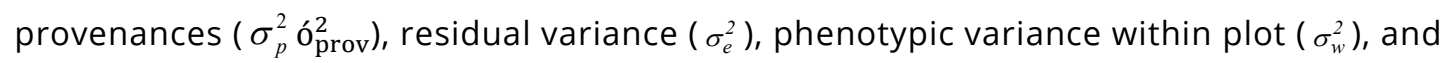
total phenotypic variance $\left(\sigma_{t p}^{2}\right)$. The estimated parameters were: the coefficient of determination of plot effects $\left(C_{p l}^{2}\right)$, coefficient of experimental variation $\left(C V_{e} \%\right)$, coefficient of individual additive genetic variation $\left(C V_{g i} \%\right)$, coefficient of genetic variation among progenies within provenances $\left(C V_{p(p)} \%\right)$, additive narrow sense heritability $\left(h_{a}^{2}\right)$, mean progeny heritability $\left(h_{m}^{2}\right)$, within-progeny heritability $\left(h_{w}^{2}\right)$, accuracy for progeny selection, assuming complete survival $(A)$, and relative coefficient of variation $\left(C V_{r}\right)$,

$$
C V_{e} \%=100\left(\frac{\sqrt{\sigma_{e}^{2}}}{\bar{x}}\right),
$$




$$
\begin{aligned}
& C V_{g i} \%=100\left(\frac{\sqrt{\sigma_{a}^{2}}}{\bar{x}}\right), \\
& C V_{p(p)} \%=100\left(\frac{\sqrt{\sigma_{p(p)}^{2}}}{\bar{x}}\right), \\
& h_{a}^{2}=\frac{\sigma_{a}^{2}}{\sigma_{a}^{2}+\sigma_{e}^{2}+\sigma_{w}^{2}}, \\
& h_{m}^{2}=\frac{0.25 \sigma_{a}^{2}}{0.25 \sigma_{a}^{2}+\frac{\sigma_{c}^{2}}{r}+\frac{0.75 \sigma_{a}^{2}+\sigma_{e}^{2}}{n r}}, \\
& h_{w}^{2}=\frac{0.75 \sigma_{a}^{2}}{0.75 \sigma_{a}^{2}+\sigma_{e}^{2}}, \\
& A=\sqrt{h_{m}^{2}}, \text { and } \\
& C V_{p(p)} \%
\end{aligned}
$$

where $\bar{x}$ is the phenotypic mean of each trait. The genetic divergence $\left(Q_{s t}\right)$ among all provenances for growth traits was estimated following (Sebbenn et al., 2003b) using:

$$
Q_{s t}=\frac{\sigma_{p}^{2}}{\sigma_{p}^{2}+\sigma_{p(p)}^{2}+\sigma_{w}^{2}} .
$$

\section{Planning of selection scenarios}

The dbh trait was used for tree selection due to ease and accuracy of measurement. Sixteen selection scenarios were tested using two strategies, each one for eight values of selection intensity of total survival in the trial $(7.6,11.5,15.3,19.1,22.9,26.8,30.6$, and 34.4\% of total survival trees; Table 2). Of these, eight involved selection among and within progenies $\left(S_{a w}\right)$ and eight involved selection only within progenies $\left(S_{w}\right)$. The genetic gain in the selection GS\%among and within progeny $\left(G s_{(a w)} \%\right)$ and within progeny $\left(G s_{(w)} \%\right)$ were estimated according to,

$$
\begin{aligned}
& G s_{(a w)} \%=100\left(\frac{i_{a} \sigma_{m} h_{m}^{2}}{\bar{x}_{a}}+\frac{i_{w} \sigma_{w} h_{w}^{2}}{\bar{x}_{w}}\right), \text { and } \\
& G s_{(w)} \%=100\left(\frac{i_{w} \sigma_{w} h_{w}^{2}}{\bar{x}_{w}}\right)
\end{aligned}
$$

respectively, where $\sigma_{m}$ and $\sigma_{w}$ are mean standard deviation of genetic variation among progeny within provenance and standard deviation of phenotypic variation within progeny, respectively, $\bar{x}_{a}$ and $\bar{x}_{w}$ are the means of dbh among and within progeny in the trial before selection, respectively. The variance effective population size for selected female and male 
individuals $\left(N_{e}\right)$ was calculated according with Bittencourt \& Sebbenn (2007) using the equation,

$$
N_{e}=\frac{0.5}{\Theta\left[\frac{n-1}{n}\right]+\frac{1+F}{2 n}}
$$

where $\Theta$ is the reproductive group of co-ancestry of selected male and female individuals, $n$ is the total selected individuals, and $F$ is the inbreeding in parental populations of selected individuals (assumed to be zero). The $\Theta$ values were estimated following Lindgren \& Mullin (1998), assuming the co-ancestry coefficient among individuals within progeny as half-sibs ( $\left.\theta_{i j}=0.125\right)$ and the sexual ratio of 1:1 (1 female: 1 male) using,

$\Theta=\frac{\sum_{i=1}^{n_{f}} \sum_{j=1}^{n_{m}} \theta_{i j} / 2 n_{f} n_{m}}{n_{p}}$

where $n_{p}, n_{f}$, and $n_{m}$ are the numbers of progeny, female and male trees selected within family. Finally, $G s \%$ and $N_{e}$ were plotted against the numbers of remaining individuals for different selection methods ( $S_{a w}$ and $S_{w}$ ). The point of intersection of $G S \% \mathrm{GS} \%$ and $D \mathrm{D}$ curves was considered the ideal number trees to remain on the population that would maximize both $G S \% \mathrm{GS} \%$ and $D$ D.

Table 2. Scenarios for selection among and within progenies $\left(S_{a w}\right)$ and within progeny $\left(S_{w}\right)$, using eighth selection intensity ( SI ).

\begin{tabular}{cccccc}
\hline Scenario & $S I(\%)$ & $n_{s}$ & $n_{p}$ & $n_{w}$ & Female/male \\
\hline 1 & \multicolumn{5}{c}{ Among and within progeny $\left(S_{a w}\right)$} \\
2 & 7.6 & 220 & 22 & 10 & $110 / 110$ \\
3 & 11.5 & 330 & 33 & 10 & $165 / 165$ \\
4 & 15.3 & 440 & 44 & 10 & $220 / 220$ \\
5 & 19.1 & 550 & 55 & 10 & $275 / 275$ \\
6 & 22.9 & 660 & 66 & 10 & $330 / 330$ \\
7 & 26.8 & 770 & 77 & 10 & $385 / 385$ \\
8 & 30.6 & 880 & 88 & 10 & $440 / 440$ \\
& 34.4 & 990 & 99 & 10 & $495 / 495$ \\
9 & & Within progeny $\left(S_{w}\right)$ & & \\
10 & 7.6 & 220 & 110 & 2 & $110 / 110$ \\
11 & 11.5 & 330 & 110 & 3 & $220 / 110$ \\
12 & 15.3 & 440 & 110 & 4 & $220 / 220$ \\
13 & 19.1 & 550 & 110 & 5 & $330 / 220$ \\
14 & 22.9 & 660 & 110 & 6 & $330 / 330$ \\
15 & 26.8 & 770 & 110 & 7 & $440 / 330$ \\
16 & 30.6 & 880 & 110 & 8 & $440 / 440$ \\
\hline
\end{tabular}

Note. $n_{s}, n_{p}$, and $n_{w}$ are the total number of selected trees, progenies, and trees within progenies, respectively.

\section{RESULTS AND DISCUSSION}

The provenance-and-progeny test presented genetic variation for all growth-phenotype traits, indicating an effective sampling strategy for the ex-situ conservation of genetic variation from five natural populations of $A$. angustifolia. Significant differences were detected by the 
LRT among provenances and progenies for all traits, with the exception of the effect of progeny on survival (Table 3). The coefficient of determination of plot effects $\left(C_{p l}^{2} \mathrm{C}_{\text {plot }}^{2}\right.$ ) was low for all traits ( $\left.C_{p l}^{2}: 0.02-0.14\right)$, as well as the coefficient of experimental variation ( $\mathrm{CV}_{e} \%: 9.1-$ 22.3\%). These results indicate that the experimental design has adequate control for the environmental variation and provides accurate estimates of genetic parameters of quantitative traits.

Table 3. Mean, mean annual increment (MAI), and likelihood-ratio test (LRT) for deviance analysis and genetic parameters for growth and survival traits in the provenance-and-progeny test.

\begin{tabular}{|c|c|c|c|c|}
\hline & $\begin{array}{l}\text { Height }(m) \\
{\left[M A I, m \cdot y^{-1}\right]}\end{array}$ & $\begin{array}{c}\mathrm{dbh}(\mathrm{cm}) \\
{\left[\mathrm{MAl}, \mathrm{cm} \cdot \mathrm{y}^{-1}\right]}\end{array}$ & $\begin{array}{l}\text { Volume }\left(m^{3}\right) \\
{\left[M A I, m^{3} \cdot y^{-1}\right]}\end{array}$ & $\begin{array}{l}\text { Survival } \\
(\%)\end{array}$ \\
\hline \multicolumn{5}{|l|}{ Mean } \\
\hline Campos do Jordão (CJ) & $8.68[0.26]$ & $12.86[0.39]$ & $0.090[0.003]$ & 91.9 \\
\hline Cunha (CU) & $9.38[0.28]$ & $13.82[0.42]$ & $0.107[0.003]$ & 88.6 \\
\hline Itararé (IT) & $8.83[0.27]$ & $13.55[0.41]$ & $0.098[0.003]$ & 86.3 \\
\hline São Joaquim (SJ) & $7.82[0.24]$ & $11.45[0.35]$ & $0.070[0.002]$ & 83.9 \\
\hline Bom Jardim da Serra (BJS) & $7.52[0.23]$ & $10.73[0.33]$ & $0.063[0.002]$ & 85.2 \\
\hline Overall mean & $8.36[0.25]$ & $12.34[0.37]$ & $0.083[0.002]$ & 87.2 \\
\hline LRT - Provenances & $48.83 * *$ & $27.07 * \star$ & $28.84 * *$ & $7.15^{* *}$ \\
\hline LRT - Progenies & $10.82 * *$ & $33.73^{* *}$ & $20.66^{* *}$ & 2.08 \\
\hline \multicolumn{5}{|l|}{ Parameter } \\
\hline $\begin{array}{l}\text { Genetic differentiation among provenances: } \\
\qquad Q_{s t}\end{array}$ & 0.152 & 0.083 & 0.088 & - \\
\hline Coefficient of determination of plot effect: $C_{p l}^{2}$ & 0.14 & 0.08 & 0.09 & 0.02 \\
\hline Coefficient of experimental variation: $\mathrm{CV}_{e} \%$ & 9.1 & 10.5 & 22.3 & 13.2 \\
\hline $\begin{array}{l}\text { Coefficient of individual genotypic variation: } \\
\qquad \mathrm{CV}_{g i} \%\end{array}$ & 11.2 & 19.8 & 39.4 & - \\
\hline $\begin{array}{c}\text { Coefficient of genetic variation among } \\
\text { progenies: } C V_{p(p)} \%\end{array}$ & 5.6 & 9.9 & 19.7 & 4.0 \\
\hline Narrow sense individual heritability: $h_{a}^{2}$ & 0.202 & 0.231 & 0.238 & - \\
\hline Progeny mean heritability: $h_{m}^{2}$ & 0.419 & 0.542 & 0.536 & 0.210 \\
\hline Additive heritability within plot: $h_{w}^{2}$ & 0.186 & 0.198 & 0.207 & - \\
\hline Accuracy of progeny selection: $A$ & 0.647 & 0.636 & 0.732 & 0.460 \\
\hline Coefficient of relative variation: $\mathrm{CV}_{r}$ & 0.614 & 0.937 & 0.885 & 0.300 \\
\hline
\end{tabular}

Note. $\mathrm{dbh}$ is the diameter at breast height; $* * P<0.01$ for qui-square test $\left(x^{2}\right)$, with one degree of freedom.

The genetic variation among provenances, and amongst progenies within provenances, can also be exploited in breeding programs to produce improved seeds for commercial reforestation and environmental recovery. The high survival rate at 33 years $(87.2 \%$, ranging among provenances from 83.9 to $91.9 \%$ ) demonstrates the overall adaptation of provenances from different geographical and climatic conditions within the trial site (Table 3). At age 18 years, the survival rate of this trial was reported as $89.7 \%$ (Sebbenn et al., 2003b), indicating a low mortality rate $(<3 \%)$ across the proceeding 15-year period (from 2000 to 2015). The IT provenance, located $50 \mathrm{~km}$ from the trial site, and the $\mathrm{CJ}$ and $\mathrm{CU}$ provenances located in a northerly direction from the Itapeva trial site exhibited greater heights (8.83-9.38 m), dbh values $(12.86-13.82 \mathrm{~cm})$, and wood volumes $\left(0.090-0.107 \mathrm{~m}^{3}\right.$.tree$\left.{ }^{1}\right)$ than the SJ and BJS provenances which originated from the south (H: 7.52-7.82 m; dbh: 10.73-11.45 $\mathrm{cm}$; Vol: $0.063-0.070 \mathrm{~m}^{3}$.tree ${ }^{-1}$ ). Mean annual increments (MAl) denote a decrease in the rate of growth as tree age increases. Whereas at 18 years, the MAI values were for height $(0.38 \mathrm{~m} / \mathrm{year}=6.88$ $\mathrm{m} / 18$ years $)$, dbh $(0.57 \mathrm{~cm} /$ year $=10.19 \mathrm{~cm} / 18$ years $)$, and Vol $\left(0.0021 \mathrm{~m}^{3} \cdot\right.$ tree $^{-1}=0.037 \mathrm{~m}^{3}$. tree $^{-1} / 18$ years) (Sebbenn et al., 2003b), at 33 years the values were $34.2 \%(=100(0.38-0.25) / 0.38), 35.1 \%$ $(=100(0.57-0.37) / 0.57)$ and $4.8 \%(=100(0.0021-0.002) / 0.0021)$ lower, respectively. 
The results indicate that great part of the genetic variation for all traits was distributed within (rather than between) provenances $\left(Q_{s t}=0.083-0.152\right.$ ) (Table 3 ). This same pattern was also reported in $A$. angustifolia for the same traits in 18 provenances at age 23 years $\left(Q_{s t}=0.045-0.073\right.$, Shimizu, 1999), 14 provenances at age 21 years $\left(Q_{s t}=0.032-0.062\right.$, Sebbenn et al., 2003b), and five provenances at age 30 years ( $Q_{s t}=0.089-0.152$, Sebbenn et al., 2004). The high genetic variation within provenances indicates the possibility of obtaining genetic gains by selection among progeny within populations and individuals within progeny. Furthermore, in general, the coefficients of individual additive genotypic variation $\left(\mathrm{CV}_{\mathrm{gi}} \%=11.2-39.4 \%\right)$ and genotypic variation among progenies ( $C V_{p(p)} \%=5.6-19.7 \%$ ) were generally high ( $>10 \%$, Resende, 2002), indicating that this trial presents a great potential to select plus trees within progenies and within progeny/provenances for breeding programs (Sebbenn et al., 2003a). Furthermore, the accuracy was high for growth traits ( $A$ $=0.65-0.79$ ), indicating a strong correlation between phenotype and genotype. The most-desirable individuals from the most-divergent progenies can be selected to the development of intrapopulation hybrids aiming at timber- or seed production (Aguiar et al., 2019). The quantification of genetic divergence between provenances is important to inform tree selection for crosses made in breeding programs. Crosses between individuals from different provenances may enhance the heterosis for the quantitative traits of economic interest (Sebbenn et al., 2003b; Aguiar et al., 2019). In addition, the results of genetic differentiation between provenances will guide seed collection from the most-divergent populations for breeding and genetic conservation programs (Silva et al., 2018).

The estimates of heritability for growth-phenotype traits indicate that higher genetic gains can be obtained by selection among progenies $\left(h_{m}^{2}: 0.419-0.524\right)$ rather than by mass selection $\left(h_{a}^{2}: 0.202-0.348\right)$ or within-progeny selection $\left(h_{w}^{2}: 0.186-0.207\right)$. Consistent with this, a high accuracy of progeny selection ( $A$ ) and the coefficient of relative variation ( $C V_{r}>0.6$ ) was observed, indicating a high possibility for genetic improvement by selection among progenies. Thus, the selection based on progeny is more precise than that based on plot or mass of individual levels within the trial.

The dbh showed the highest values of heritabilities and thus presents greatest genetic control, so it is recommended as the trait for selection of trees for breeding. The optimization was the tool used to achieve the balance between $N_{e}$ and genetic gain for dbh to guarantee the genetic conservation of provenances and produce seeds with a reasonable level of improvement. Of the simulated selection methods tested, the selection among and within progenies $\left(S_{a w}\right)$ resulted in the greatest genetic gains, regardless of the selection intensity (Figure 1, Table 4). Group coancestry for female and male trees $(\Theta)$ predicts low expected inbreeding $(<0.01)$ in produced seeds on random mating for all scenarios of selection in the seedling seed orchard test (Table 4). As the number of selected individuals decreased with increased selection intensity, the genetic gain increased and the $N_{e}$ decreased for both methods, but was more pronounced for the $S_{a w}$ method. The expected genetic gains with selection ranged from $19.9 \%$ with 220 selected trees in the $S_{a w}$ method to $8.6 \%$ with 990 selected trees in the $S_{w}$ method. As expected, $s_{w}$ was the method that maintained most of the original effective population size, with selection intensities ranging from 146.9 to 304.8, where $S_{a w}$, ranged from 63.1 to 283.1 (Figure 2). The different simulated intensity of selection had different impacts on the values of genetic gain $(G s \%)$ and $N_{e}$, according to the selection method (Figure 3). The optimal situation for the $S_{a w}$ method is the selection of 660 individuals (66 progenies, each one with 10 individuals), resulting in a genetic gain of $12.7 \%$ and $N_{e}$ of 188.8, where for situation for $S_{w}$ method, is the selection of 550 individuals (5 individuals within each progeny), resulting in a genetic gain of $11.0 \%$ and $N_{e}$ of 244.7 (Figure 3, Table 4). The $S_{a w}$ method decreases the $N_{e}$ in $50.6 \%$ in relation to the original population, where $S_{w}$ method decreases about $35.9 \%$. 


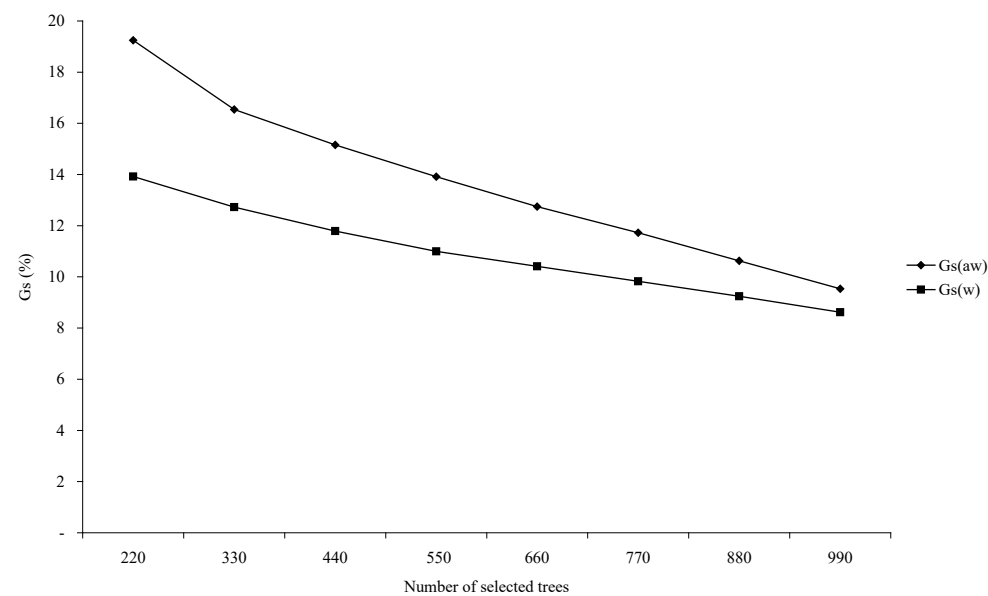

Figure 1. Genetic gain related to the number of selected individuals according to the selection method: among and within progeny $\left(G s_{(a w)}\right)$ and within progenies $\left(G s_{(w)}\right)$.

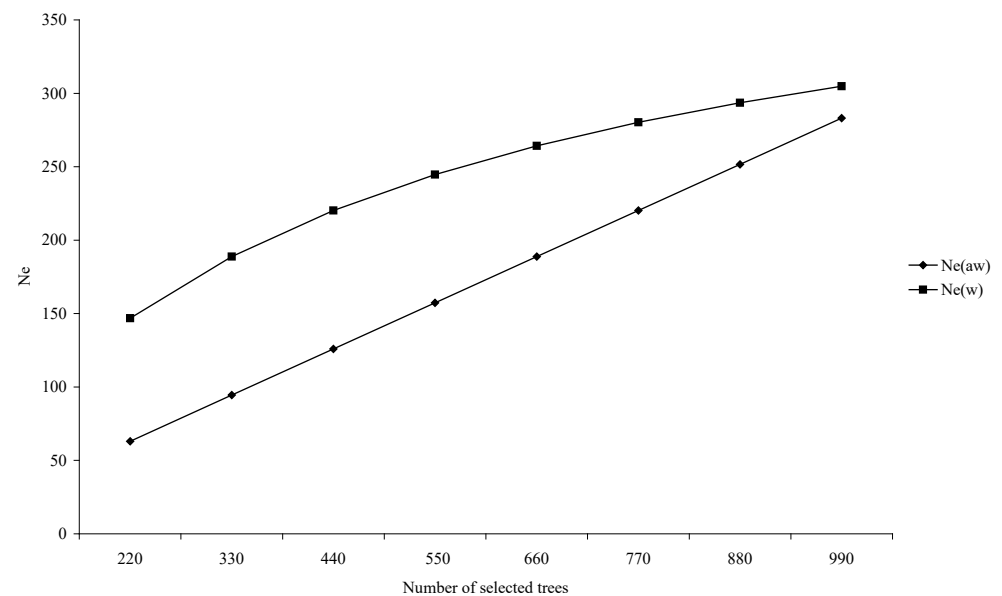

Figure 2. Relation between effective population size $\left(N_{e}\right)$ related to the number of selected individuals according to the selection method: among and within progeny $\left(N_{e(a w)}\right)$ and within progenies $\left(N_{e(w)}\right)$.

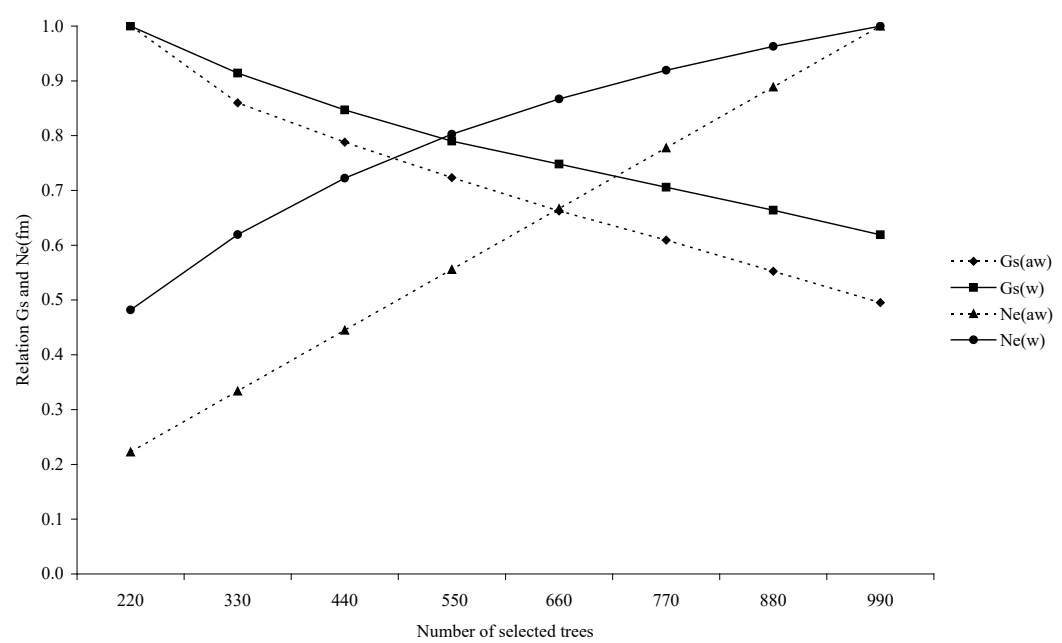

Figure 3. Optimal point (crossing the lines) to select the number of trees based on genetic gain ( Gs ) and effective population size $\left(N_{e}\right)$ for selection among and within progeny $\left(G s_{(a w)}, N_{e(a w)}\right)$ and within

$$
\text { progeny }\left(G s_{(w)}, N_{e(w)}\right) \text {. }
$$


Table 4. Genetic gain $(G s \%)$, improved mean $\left(\bar{x}_{i}\right)$, group of coancestry among females and males $(\Theta)$, and reproductive effective population size $\left(N_{e}\right)$ for diameter at breast height (dbh), according to the selection among and within progeny $\left(S_{a w}\right)$, within progeny $\left(S_{w}\right)$ and selection intensity $(S I)$ to convert the provenance-and-progeny test in a seedling seed-orchard.

\begin{tabular}{ccccccccc}
\hline Scenario & $S I(\%)$ & $n_{s}$ & \multicolumn{7}{c}{$n_{p} / n_{w}$} & $n_{f} / n_{m}$ & $G s \%$ & $\bar{x}_{i}$ (cm) & $\Theta$ & $N_{e}$ \\
\hline \multicolumn{7}{c}{ Among and within progeny $\left(S_{a w}\right)$} \\
2 & 7.6 & 220 & $22 / 10$ & $110 / 110$ & 19.2 & 14.71 & 0.00568 & 63.1 \\
3 & 11.5 & 330 & $33 / 10$ & $165 / 165$ & 16.5 & 14.38 & 0.00379 & 94.5 \\
4 & 15.3 & 440 & $44 / 10$ & $220 / 220$ & 15.2 & 14.21 & 0.00284 & 125.9 \\
5 & 19.1 & 550 & $55 / 10$ & $275 / 275$ & 13.9 & 14.06 & 0.00227 & 157.3 \\
6 & 22.9 & 660 & $66 / 10$ & $330 / 330$ & 12.7 & 13.92 & 0.00189 & 188.8 \\
7 & 26.8 & 770 & $77 / 10$ & $385 / 385$ & 11.7 & 13.79 & 0.00162 & 220.2 \\
8 & 30.6 & 880 & $88 / 19$ & $440 / 440$ & 10.6 & 13.66 & 0.00142 & 251.6 \\
& 34.4 & 990 & $99 / 10$ & $495 / 495$ & 9.5 & 13.52 & 0.00126 & 283.1 \\
9 & & & Within progeny $\left(S_{w}\right)$ & & & \\
10 & 11.5 & 330 & $110 / 3$ & $220 / 120$ & 12.7 & 13.92 & 0.00114 & 188.8 \\
11 & 15.3 & 440 & $110 / 4$ & $220 / 220$ & 11.8 & 13.80 & 0.00114 & 220.3 \\
12 & 19.1 & 550 & $110 / 5$ & $330 / 220$ & 11.0 & 13.70 & 0.00114 & 244.7 \\
13 & 22.9 & 660 & $110 / 6$ & $330 / 330$ & 10.4 & 13.63 & 0.00114 & 220.3 \\
14 & 26.8 & 770 & $110 / 7$ & $440 / 330$ & 9.8 & 13.56 & 0.00114 & 280.2 \\
15 & 30.6 & 880 & $110 / 8$ & $440 / 440$ & 9.2 & 13.49 & 0.00114 & 293.6 \\
16 & 34.4 & 990 & $110 / 9$ & $550 / 440$ & 8.6 & 13.41 & 0.00114 & 304.8 \\
\hline
\end{tabular}

Population mean, $\bar{x}=12.34 \mathrm{~cm} ; n_{s}, n_{p}$, and $n_{w}$ are the total number of selected trees, progenies and trees within progeny, respectively; $n_{f}$ and $n_{m}$ is the number of selected female and male trees within progeny, $n_{f}$ and $n_{m}$ is the number of selected female and male trees within progeny, respectively; the $N_{e}$ for provenance-and-progeny test is 382 .

For ex-situ conservation of the population in the provenance-and-progeny test, the optimal point of selection was achieved for $S_{w}$ with the selection of 550 individuals ( $G s \%=$ 11.0\%; $N_{e}=244.7$ ), three females and two males of each progeny, resulting in a seedling seedorchard with 330 female and 220 male trees. The genetic gain predicts that random mating in the seedling seed-orchard will produce seeds that are expected reach $13.70 \mathrm{~cm}$ of dbh at age 33-year in plantations established in similar environmental characteristics of the Itapeva Experimental Station. The collection of seeds of all female trees will result in new forest for commercial or environmental reforestation with low inbreeding $(F=\Theta<1 \%)$ and $a N_{e}>150$. Values of $N_{e}>150$ are expected to maintain $90 \%$ of the genetic diversity of the founder population for 10 generations (Sebbenn, 2006). The implementation of the $S_{w}$ strategy will conserve the genetic variability of all five provenances and progeny within provenances, retain more than $64 \%(=100(244.7 / 382))$ of the actual $N_{e}$ and produce seeds with $11 \%$ of genetic gain.

Alternatively, to increase the genetic gain for commercial reforestation a clonal seed orchard could be established using vegetative propagation of selected trees in the trial based on high mass-selection intensity among and within progeny. For example, the selection of 30 of the best trees (1\%), each one from a different progeny, being 15 female and 15 males will result in a genetic gain of $35 \%$ for $\mathrm{dbh}$ and a $N_{e}$ of 30 . The selection of only one tree per progeny avoids crossing between related individuals and inbreeding in the produced seeds (Sebbenn et al., 2003b; Aguiar et al., 2019).

It is a principle of biology that increased vigor, or the most-rapid growth phenotype of an organism represents optimum ecological fitness (Hallsworth, 2018). During the 33-year period, each value for mean annual dbh increase became progressively less, showing clear signs of the need of performing a selective thinning. The number of individuals is still very high. The selective thinning based on the optimal point of selection within progeny will provide a 
seedling seed-orchard composed of more productive trees with relevant genetic variability. Lastly, as the species is dioecious; the sex ratio of remaining trees should be considered to ensure a favorable supply of high-quality seeds. We recommend keeping the same number of males and females for each progeny.

\section{CONCLUSIONS}

Provenances and progenies within provenances present genetic differences for growth traits, which can be used to obtain genetic gains by selection among progeny and individuals within progeny. Conversion of this trial into a seedling seed-orchard is recommended to provide high-quality improved seeds for growth traits to be used in reforestations and concomitantly ensure the ex-situ conservation of the populations. For the purposes of combined ex-situ conservation and tree-improvement strategies, the most-successful selection method is high-intensity selection within progenies. This must be carried out only by selection of three females and two males within progeny. Thus, the genetic variation among A. angustifolia provenances and progenies within provenances and the effective population size will be maintained, and a substantial genetic gain (11\%) can be obtained, providing a higher quality seed production.

\section{REFERENCES}

Aguiar, B. I., Freitas, M. L. M., Tavares, Y. R., Tambarussi, E. V., Zanatto, B., Gandara, F. B., Paludeto, J. G. Z., Silva, D. Y. B. O., Silva, J. R., Moraes, M. L. T., Longui, E. L., Zanata, M., \& Sebbenn, A. M. (2019). Genetic control of silvicultural traits in Balfourodendron riedelianum (Engl.) Engl. Silvae Genetica, 68(1), 73-78. http://dx.doi.org/10.2478/sg-2019-0013.

Auler, N. M. F., Reis, M. S. D., Guerra, M. P., \& Nodari, R. O. (2002). The genetics and conservation of Araucaria angustifolia: I. Genetic structure and diversity of natural populations by means of nonadaptive variation in the state of Santa Catarina, Brazil. Genetics and Molecular Biology, 25(3), 329338. http://dx.doi.org/10.1590/S1415-47572002000300014.

Bittencourt, J. V. M., \& Sebbenn, A. M. (2007). Patterns of pollen and seed dispersal in a small, fragmented population of the wind-pollinated tree Araucaria angustifolia in southern Brazil. Heredity, 99(6), 580-591. PMid:17928810. http://dx.doi.org/10.1038/sj.hdy.6801019.

Bittencourt, J. V. M., \& Sebbenn, A. M. (2009). Genetic effects of forest fragmentation in high-density Araucaria angustifolia populations in Southern Brazil. Tree Genetics \& Genomes, 5(4), 573-582. http://dx.doi.org/10.1007/s11295-009-0210-4.

Danner, M. A., Ribeiro, J. Z., Zanette, F., Bittencourt, J. V. M., \& Sebbenn, A. M. (2013). Impact of monoecy in the genetic structure of a predominately dioecious conifer species, Araucaria angustifolia (Bert.) O. Kuntze. Plant Systematics and Evolution, 299(1-2), 949-958. http://dx.doi.org/10.1007/s00606-0130775-0.

Duarte, L. D., Prieto, P. V., \& Pillar, V. D. (2012). Assessing spatial and environmental drivers of phylogenetic structure in Brazilian Araucaria forests. Ecography, 35(10), 952-960. http://dx.doi.org/10.1111/j.1600-0587.2011.07193.x.

Ferreira, D. K., Nazareno, A. G., Mantovani, A., Bittencourt, R., Sebbenn, A. M., \& dos Reis, M. S. (2012). Genetic analysis of 50-year old Brazilian pine (Araucaria angustifolia) plantations: implications for conservation planning. Conservation Genetics, 13(2), 435-442. http://dx.doi.org/10.1007/s10592-0110296-8.

Flower, C., Fant, J., Hoban, S., Knight, K., Steger, L., Aubihl, E., Gonzalez-Meler, M., Forry, S., Hille, A., \& Royo, A. (2018). Optimizing conservation strategies for a threatened tree species: in situ conservation of white ash (Fraxinus americana L.) genetic diversity through insecticide treatment. Forests, 9(4), 202. http://dx.doi.org/10.3390/f9040202.

Fonseca, L. M., Silva, F. T., Bona, N. P., Stefanello, F. M., Borges, C. D., Dias, A. R. G., \& Zavareze, E. D. (2020). Aerogels from native and anionic corn starches loaded with pinhao (Araucaria angustifolia) coat extract: anti-tumor activity in C6 rat glioma cells and in vitro digestibility. Stärke, 72(7-8), 1900280. http://dx.doi.org/10.1002/star.201900280.

Goldringer, I., van Frank, G., d'Yvoire, C. B., Forst, E., Galic, N., Garnault, M., et al (2020). Agronomic evaluation of bread wheat varieties from participatory breeding: a combination of performance and robustness. Sustainability, 12(1), 2071-1050. http://dx.doi.org/10.3390/su12010128. 
Haddad, N. M., Brudvig, L. A., Clobert, J., Davies, K. F., Gonzalez, A., Holt, R. D., Lovejoy, T. E., Sexton, J. O., Austin, M. P., Collins, C. D., Cook, W. M., Damschen, E. I., Ewers, R. M., Foster, B. L., Jenkins, C. N., King, A. J., Laurance, W. F., Levey, D. J., Margules, C. R., Melbourne, B. A., Nicholls, A. O., Orrock, J. L., Song, D. X., \& Townshend, J. R. (2015). Habitat fragmentation and its lasting impact on Earth's ecosystems. Science Advances, 1(2), e1500052. PMid:26601154. http://dx.doi.org/10.1126/sciadv.1500052.

Hallsworth, J. E. (2018). Stress-free microbes lack vitality. Fungal Biology, 122(6), 379-385. PMid:29801781. http://dx.doi.org/10.1016/j.funbio.2018.04.003.

Hummel, J., Gee, C. T., Südekum, K. H., Sander, P. M., Nogge, G., \& Clauss, M. (2008). In vitro digestibility of fern and gymnosperm foliage: implications for sauropod feeding ecology and diet selection. Proceedings. Biological Sciences, 275(1638), 1015-1021. PMid:18252667. http://dx.doi.org/10.1098/rspb.2007.1728.

Lacerda, A. E. (2016). Conservation strategies for Araucaria Forests in Southern Brazil: assessing current and alternative approaches. Biotropica, 48(4), 37-544. http://dx.doi.org/10.1111/btp.12317.

Lindgren, D., \& Mullin, T. J. (1998). Relatedness and status number in seed orchard crops. Canadian Journal of Forest Research, 28(2), 76-283. http://dx.doi.org/10.1139/x97-217.

Mantovani, A., Morellato, L. P., \& Dos Reis, M. S. (2006). Internal genetic structure and outcrossing rate in a natural population of Araucaria angustifolia (Bert.) O. Kuntze. The Journal of Heredity, 97(5), 466472. PMid:16982668. http://dx.doi.org/10.1093/jhered/esI031.

Medina-Macedo, L., de Lacerda, A. E. B., Sebbenn, A. M., Ribeiro, J. Z., Soccol, C. R., \& Bittencourt, J. V. M. (2016). Using genetic diversity and mating system parameters estimated from genetic markers to determine strategies for the conservation of Araucaria angustifolia (Bert.) O. Kuntze (Araucariaceae). Conservation Genetics, 17(2), 413-423. http://dx.doi.org/10.1007/s10592-015-0793-2.

Peralta, R. M., Koehnlein, E. A., Oliveira, R. F., Correa, V. G., Corrêa, R. C. G., Bertonha, L., Bracht, A., \& Ferreira, I. C. F. R. (2016). Biological activities and chemical constituents of Araucaria angustifolia: an effort to recover a species threatened by extinction. Trends in Food Science \& Technology, 54(1), 8593. http://dx.doi.org/10.1016/j.tifs.2016.05.013.

Pereira, J. M., Vasconcellos, R. L. F., Pereira, A. P. A., Sturmer, S. L., Silva, A. M. M., Baretta, D., Bonfim, J. A., \& Cardoso, E. J. B. N. (2020). Reforestation processes, seasonality and soil characteristics influence arbuscular mycorrhizal fungi dynamics in Araucaria angustifolia forest. Forest Ecology and Management, 460(6), 117899. http://dx.doi.org/10.1016/j.foreco.2020.117899.

Perotti, J. C., da Silva Rodrigues-Corrêa, K. C., \& Fett-Neto, A. G. (2015). Control of resin production in Araucaria angustifolia, an ancient South American conifer. Plant Biology, 17(4), 852-859. PMid:25545585. http://dx.doi.org/10.1111/plb.12298.

Pires, C. L. S., Barbim, D., Gurfinkel, J., \& Marcandes, M. A. P. (1983). Teste de progênie de Araucaria angustifolia (Bert) O. Ktze. em Campos do Jordão. Silvicultura, 8(1), 440-445.

Reis, M. S., Montagna, T., Mattos, A. G., Filippon, S., Ladio, A. H., Marques, A. C., Zechini, A. A., Peroni, N., \& Mantovani, A. (2018). Domesticated landscapes in Araucaria Forests, Southern Brazil: a multispecies local conservation-by-use system. Frontiers in Ecology and Evolution, 6(2), 11. http://dx.doi.org/10.3389/fevo.2018.00011.

Reitz, R., \& Klein, R. M. (1966). Araucariáceas (62 p.). Itajaí: Herbário Barbosa Rodrigues.

Resende, M. D. V. (2002). Genética biométrica e estatística no melhoramento de plantas perenes (975 p.). Brasília: EMBRAPA Informação Tecnológica.

Resende, M. D. V. (2016). Software Selegen-REML/BLUP: a useful tool for plant breeding. Crop Breeding and Applied Biotechnology, 16(4), 330-339. http://dx.doi.org/10.1590/1984-70332016v16n4a49.

Sant'Anna, C. S., Sebbenn, A. M., Klabunde, G. H. F., Bittencourt, R., Nodari, R. O., Mantovani, A., \& dos Reis, M. S. (2013). Realized pollen and seed dispersal within a continuous population of the dioecious coniferous Brazilian pine [Araucaria angustifolia (Bertol.) Kuntze]. Conservation Genetics, 14(3), 601-613. http://dx.doi.org/10.1007/s10592-013-0451-5.

Schmidt, I. B., de Urzedo, D. I., Piña-Rodrigues, F. C. M., Vieira, D. L. M., de Rezende, G. M., Sampaio, A. B., \& Junqueira, R. G. P. (2019). Community-based native seed production for restoration in Brazilthe role of science and policy. Plant Biology, 21(3), 389-397. PMid:29779253. http://dx.doi.org/10.1111/plb.12842.

Sebbenn, A. M. (2006). Mating system in tropical tree species and its implications for the selection of seed trees for environmental reforestation. In A. R. Higa \& L. D. Silva (Eds.), Seed orchards of native forest species (pp. 93-138). FUPEF, Curitiba. 
Sebbenn, A. M., Pontinha, A. A. S., Freitas, A. S., \& Freitas, J. (2004). Variação genética em cinco procedências de Araucaria angustifolia (Bert.) O. Ktze. no sul do Estado de São Paulo. Revista do Instituto Florestal, 16(2), 91-99.

Sebbenn, A. M., Pontinha, A. A. S., Gianotti, E., \& Kageyama, P. Y. (2003a). Genetic variation in provenance-progeny test of Araucaria angustifolia (Bert.) O. Ktze. in São Paulo, Brasil. Silvae Genetica, 52(5-6), 181-184.

Sebbenn, A. M., Pontinha, A. A. S., Giannotti, E., \& Kageyama, P. Y. (2003b). Variação genética entre e dentro de procedências e progênies de Araucaria angustifolia no Sul do Estado de São Paulo. Revista do Instituto Florestal, 15(2), 109-124.

Shimizu, J. Y. (1999). Variação entre procedências de Araucária em Ribeirão Branco (SP) aos vinte e três anos de idade. Boletim de Pesquisa Florestal, 38(1), 89-102.

Silva, J. R., Santos, W. D., Moraes, M. L. T., Shimizu, J. Y., Sousa, V. A., \& Aguiar, A. V. (2018). Seleção de procedências e progênies de Araucaria angustifolia (Bert.) O. Kuntze para produção de madeira e pinhão. Scientia Forestalis, 46(120), 519-531. https://dx.doi.org/10.18671/scifor.v46n120.01.</jrn>

Silva, P. I. T., Silva-Junior, O. B., Resende, L. V., Sousa, V. A., Aguiar, A. V., \& Grattapaglia, D. (2020). A 3K Axiom ${ }^{\circledR}$ SNP array from a transcriptome-wide SNP resource sheds new light on the genetic diversity and structure of the iconic subtropical conifer tree Araucaria angustifolia (Bert.) Kuntze. PLoS One, 15(8), e0230404. PMid:32866150. http://dx.doi.org/10.1371/journal.pone.0230404.

Sousa, V. A., Reeves, P. A., Reilley, A., de Aguiar, A. V., Stefenon, V. M., \& Richards, C. M. (2020). Genetic diversity and biogeographic determinants of population structure in Araucaria angustifolia (Bert.) $O$. Ktze. Conservation Genetics, 21(2), 217-229. http://dx.doi.org/10.1007/s10592-019-01242-9.

Stefenon, V. M., Klabunde, G., Lemos, R. P. M., Rogalski, M., \& Nodari, R. O. (2019). Phylogeography of plastid DNA sequences suggests post-glacial southward demographic expansion and the existence of several glacial refugia for Araucaria angustifolia. Scientific Reports, 9(1), 2752. PMid:30808955. http://dx.doi.org/10.1038/s41598-019-39308-w.

Urzedo, D. I., Fisher, R., Piña-Rodrigues, F. C. M., Freire, J. M., \& Junqueira, R. G. P. (2019). How policies constrain native seed supply for restoration in Brazil. Restoration Ecology, 27(4), 768-774. http://dx.doi.org/10.1111/rec.12936.

Zandavalli, R. B., \& Dillenburg, L. R. (2015). Response of Araucaria angustifolia seedlings to root competition in three different plant communities of southern Brazil. New Zealand Journal of Botany, 53(3), 139-154. http://dx.doi.org/10.1080/0028825X.2015.1043922.

Zechini, A. A., Lauterjung, M. B., Candido-Ribeiro, R., Montagna, T., Bernardi, A. P., Hoeltgebaum, M. P., Mantovani, A., \& dos Reis, M. S. (2018). Genetic conservation of brazilian pine (Araucaria angustifolia) through traditional land use. Economic Botany, 72(2), 166-179. http://dx.doi.org/10.1007/s12231018-9414-6.

Authors' contributions: AASP, BMS and MLMF: supervision; JARM, AVA and AMS: formal analysis, writing original draft; ASM and JEH: writing, review \& editing. 